\title{
A Model to Align Organizational Culture to Lean Culture
}

\author{
Mehrsa Taherimashhadi iD, Imma Ribas iD \\ ETSEIB, Universitat Politècnica de Catalunya (Spain) \\ mehrsa.taherimashhadi@upc.edu,imma.ribas@upc.edu
}

Received: November 2017

Accepted: December 2017

\begin{abstract}
:
Purpose: Since the emergence of Lean Manufacturing many organizations strived to implement it. Nonetheless, sustainable Lean transformation is not as easy as to be simply achieved. Several aspects need to be taken into account before Lean implementation which national and organizational culture are important. By considering influences of national culture on the organizational culture, this paper aims at proposing an evaluation model to determine the cultural weaknesses of an organization and give some recommendations to manage people before implementing Lean.
\end{abstract}

Design/methodology/approach: This research has been conducted based on literature review survey and semi-structured interviews. Research papers, conference proceedings, books, and official websites regarding Lean philosophy were reviewed to find the influence of national culture in Lean implementation. Different databases were scrutinized, from 2015 to 2017, containing Scopus and Web of Science with the time period of 1996-2016. A set of key terms and their combinations were used including: Toyota Production system, Lean production, Lean manufacturing, Lean management, Transformation, Implementation, Barriers/ Impediments/Challenges/Difficulties, Human resources, Success factors, Organizational culture, and National culture.

Findings: The proposed evaluation model is a guide for organizations to determine cultural misalignments between the corporate culture and the Lean culture before its implementation and gives some managerial recommendations to correct them.

Originality/value: This study is the first attempt to integrate the national models with Lean culture to provide an evaluation model and some recommendations to help the organization to align its culture to Lean culture before its implementation.

Keywords: lean manufacturing, Toyota production system, organizational culture, national culture, lean implementation

\section{Introduction}

Despite its name, Lean Manufacturing does not deal with only production process. It is considered as interrelated system of soft and hard practices underlined by set of beliefs and values. Hard practices refer to technical tools whereas soft practices concern people, which they are equally crucial for achieving long term superior performance (Bortolotti, Boscari \& Danese, 2015). While organizational culture determines the success of Lean (Atkinson, 2010; Gupta \& Jain, 2013), many organizations focus on only the deployment of tools without considering less visible areas including cultural aspects (Hines, Found, Griffiths, \& Harrison, 2011; Atkinson, 2010; Nordin, Deros, Wahab, \& Rahman, 2012; Dombrowski \& Mielke, 2014; Martins, Affonso, Tamayo, Lamouri, \& Ngayo, 2015). 
In fact, management practices for Lean and Lean culture is easy to grasp but difficult to execute consistently (Wilson, 2009) which are neglected in most descriptions of Lean (Mann, 2014). Lean grew naturally out of the workings of Toyota over five decades. As a result, it has never been written down, and Toyota's workers often are not able to articulate it (Spear \& Bowen, 1999). In fact, Toyota views employees not just as pairs of hands but as knowledge workers who accumulate the wisdom of experience (Takeuchi, 2008). Therefore, Lean manufacturing is a combined system of ideas (Dailey, Wieckhorst \& Welch, 2003) and workers are considered in a position of thinker, continuously looking for improvement and wastes (Alves, Dinis-Carvalho, \& Sousa, 2012).

Toyota is intent on keeping common underlying values of Lean culture in all its subsidiaries around the world which originated from Japanese culture and religion. However, the way those values are lived out is adapted to the local context (Pheng \& Shang, 2011; Parkes, 2014; Liker \& Convis, 2011). Although Parkes (2014) considers influence of national culture stronger than organizational ones in applying Lean philosophy, it is necessary to consider both, organizational and national culture, to understand the failure of Lean implementation in Japanese companies and the success in non-Japanese organizations.

National culture is a key role in adoption of new forms of work organizations (Cagliano, Caniato, Golini, Longoni, \& Micelotta, 2011). According to Mike \& Slocum (2003), mutual adaptations take place rather easily whereas they can also create cultural conflicts and acculturative stress during intercultural interactions. Therefore, differences in reactions of people to get used to new way of working, how to convince and motivate them to participate in transformation to Lean are crucial issues that managers should know.

This research aims at proposing an evaluation model to examine organizational and national culture adaptations before implementing Lean, determine cultural weaknesses of an organization, and give some recommendations to align the corporate culture to the Lean culture before its implementation. The model is based on both literature review and interview survey on these topics.

The rest of the paper is structured as follows, section 2 describes the research methodology, section 3 is devoted to the literature review, section 4 proposes evaluation model, section 5 discusses the evaluation model, its strengths, as well as limitations, and finally, section 6 concludes.

\section{Research Methodology}

Literature review were conducted to identify how organizational and national cultural factors influence Lean implementation. The literature review gave us theoretical frameworks that was later contrasted and extended with an interview survey with a professional expert who is working as Lean implementation consultant in various countries including France, UK, US, Spain, and South America for many years. The semi-structured interviews were done twice with the same person. Different sets of open ended questions were prepared for each interview based on successful factors, practices, and challenges that we defined from our research purpose and review of previous studies. The first interview focused mainly on success factors and related practices influencing Lean. The second one, with aim at considering the national context, was focused in getting more knowledge on employee's behaviour and reactions in different countries during the process of transferring to Lean. For identifying questions, we used work organisation practices classified by Olivella, Cuatrecasas and Gavilan (2008).

\section{Literature Review}

Since the emergence of Lean philosophy, many authors tried to describe Lean Manufacturing concisely whereas it seems there is no consensus on a definition and the associated characteristics (Shah \& Ward, 2003; Hines, Holweg, \& Rich, 2004; Dahlgaard \& Mi Dahlgaard-Park, 2006; Pettersen, 2009; Taylor, Taylor, \& McSweeney, 2013). According to Pettersen (2009), the divergent opinions cause confusions both on theoretical and practical level.

In addition, during implementation of Lean, organizations confront distinctive problems. Every organization must identify and solve its own challenges based on variables of its process, place, people, and any other unique factors (Bhasin, 2012b; Bhasin 2012a; Liker \& Convis, 2011). Difficulties can be explained partly by the nature of Lean implementation, which is complex, context dependent, time consuming and requires a substantial amount of human resources and effort (Marodin \& Saurin, 2015). Some special issues are created during Lean implementation 
due to the size of plants. According to Bhasin (2012b), larger organizations perform better in Lean environment since they consider Lean philosophy as ideology. However, small to Medium enterprises (SMEs) may confront specific problems due to lack of resources availability (Achanga, Shehab, Roy, \& Nelder, 2006; Nordin et al., 2012; Kull, Yan, Liu, \& Wacker, 2014; Dora, Kumar \& Gellynck, 2016; Zhou, 2016).

Economic development is also an important aspect. As an example, the study of Al-Najem (2014) reveals different challenges in Arab countries including language barriers, because most instructions need to be translated in Arabic, and deficiencies in quality workers in terms of education and skills; technology; government attention; know-how regarding Lean production; market competitiveness; and urgency for adopting Lean production. Additionally, according to Salem, Musharavati, Hamouda and Al-Khalifa (2016), budget issues may not be considered as impediments to Lean manufacturing implementation in wealthy countries such as Qatar. Whereas, supplying financial resources in countries facing negative growth rate in manufacturing sector is not probably an easy task to do such as Lebanon and Syria reported by El-khalil and Farah (2013).

According to Hines et al. (2011), effective strategy, alignment, and leadership are a good start for transformation. Other key elements are dependent to social norms, characteristics of individuals themselves, how they are communicated and trained. In addition, Worley and Doolen (2006) assert that management support impact Lean manufacturing implementation both negatively and positively. In fact, lack of leadership commitment may lead to a host of other issues, including limited access to resources, lengthy decision-making processes, and communication breakdowns (Scherrer-Rathje, Boyle, \& Deflorin, 2009).

Moreover, Angelis, Conti, Cooper and Gill (2011) explored whether Lean characteristics inherently enhance or impede worker commitment. They also provided insights into the role that specific work practices play. Enhancing commitment appears to be conditional, depending on the effectiveness of management in designing and operating Lean techniques as well as human resource policies and practices. According to Hines et al. (2011), the engagement of people in Lean transformation starts with employees' acceptance. In fact, at first, people resist to the changes when they do not have enough knowledge and the clear awareness of what Lean philosophy is. If they have correct perception of Lean benefits, broad utilizations of tools would be possible. Moreover, the commitment of employees will improve during institutionalization of Lean as a permanent functioning and internalizing it in the whole organization.

Pakdil and Leonard (2015) assert that successful implementation of Lean requires a balanced organizational culture meaning that flexibility and uniformity are both valued. The organization is aware of both internal and external influences that necessitate change or uniformity in member behaviours. Abrahamsson and Isaksson (2012) along with Sisson and Elshennawy (2015) recommend that organizations should apply a customized and personalized version of Toyota's culture. However, there is often lack of a deeper understanding of how people and organizations function in terms of culture. Culture is as significant and complex as it is difficult to understand and use in a thoughtful way (Alvesson, 2012).

Langstrand and Elg (2012) viewed organizations as containing number of inter-dependent and interlocking routines all of which influence people's way of thinking as well as behaviour. Culture shapes patterns of behaviour, thinking and speech of one group that makes members recognizable from another. In fact, organizational culture is an invisible but powerful force that influences the behaviour of members of that group. Wilson (2009) in along with Mike \& Slocum (2003) refer to culture as a collection of silent rules and traditions since people within the culture, especially rule-makers, simply do not see what is happening within their own culture.

Alvesson (2012) also asserts that culture is not primarily inside people's heads, but somewhere between the heads of a group where symbols and meanings are expressed publicly in work group interactions, in board meetings, and also in material objects. It is meaning of aspect of what is being expressed socially and it is both visible and invisible at the same time. As stated by Schein (2010), culture is referred to the climate and practices that organizations develop around their handling of people or to the espoused values of an organization. Therefore, in line with Reider (2014), it is basic business principles that form the culture of the organization and enable it to operate smoothly and flexibly or create barriers to effective operations. It enables some employees to adapt easily to the organizational norms and others to fight against them. Even in the same organization, employees do not see 
everything alike. Hofstede, Hofstede and Minkov (2010) assert that one of the reasons why so many solutions do not work is that differences in thinking among partners have been ignored.

Yokozawa et al. (2010) assert that the Japanese companies are still experiencing many difficulties in transferring their management systems into host countries. This could be as result of national culture differences which impact on responses of people to the same issue (Schneider \& De Meyer, 1991). Actually, the reaction of people to a specific situation depends on their personal perception that rooted in their national culture. They will resist adapting to organizational priorities set by managers that are not compatible to their values. Lau and Ngo (1996) also confirm that culture of organizations established in a single country setting varies according to the culture of their home countries and these differences in value-orientations affect the employee's satisfactions and organizational commitment.

Moreover et al. (2015) assert employee's satisfactions are culturally dependable to the characteristics of the job including being interesting, the security, advancement opportunity, and good relationship with managers and these job characteristics vary across countries. Wangwacharakul, Berglund, Harlin and Gullander (2014) examine dependent concepts on local company context in implementation of Lean and high dependency has been found in the following concepts: Operational development, Continuous improvement, Goal oriented teams, Cross functional work, Organizational design, and Leaderships.

Parkes (2016) claims that British national culture is not consistent with characteristics of Lean and transforming is not something impossible but it takes more time to adapt to Lean culture. Kidd and Kanda (2000) compared the production manager of Japan and Britain in implementing strategic plans and understood that the cultural inconsistency of British and Japanese people impacts strongly. Their major difference appears in their communication style. Despite the Japanese, the study reveals that British managers tend to broader informal contacts and as result of their low context culture, similar to US and Swiss, they need the explicit share of information.

As reported by Fenwick, Edwards and Buckley (2003), cultural conflicts could arise even with the familiarity in language, past and culture. Despite the similar culture of Britain and Australia, the authors reveal that lack of cultural preparedness creates unanticipated problems with routine interpersonal interactions. James and Jones (2014) examine difficulties that Toyota experienced in process of transferring its cultural paradigm into its subsidiary established in India. The authors found that misreading the host nation's cultural and social environment as well as mishandling its people management portfolio could lead to unproductive outcomes for the parent organization.

Zimmermann and Bollbach (2015) point out China's traditional norms of management, education, and legal systems are cultural barriers to achieve continuous improvement targets. The Netherlands are severally reported as the challenging country for transfer of Kaizen (Yokozawa, Steenhuis \& de Bruijn, 2012; Yokozawa \& Steenhuis, 2013). In the international transfer of Kaizen, Yokozawa et al. (2012) confirms that the appropriate organizational culture is clan culture despite the hierarchical culture. Yokozawa and Steenhuis (2013) also assert that the transformation is culturally dependable on the high level of discipline and eagerness of employees. The authors introduce Japan as country with high level and the Netherlands with low level in both factors.

Hofstede (1984) examined national culture effects on management and identified six dimensions to characterize basic differences among nations. In 1991, the University of Pennsylvania conducted the GLOBE Project to extend Hofstede's work and proposed three new dimensions (House, Hanges, Javidan, Dorfman, \& Gupta, 2004). In 1998, a new model was developed by Trompenaars and Hampden-Turner (1997). The model includes nine dimensions that explain how national cultural differences affect doing a business and some recommendations according to Mind Tools Coporation (2014) that use Trompenaars et al. (1997) model to manage people from different cultures.

Cagliano et al. (2011) assert that there is no cultural profile or single cultural dimension that is dominant in fostering the adoption of the overall new forms of work organizations and high performance work systems that highlight human resource practices such as team work, multi-skilling, delegation, job enrichment, job enlargement, training, 
and involvement. However, several studies applied national cultural models to figure out if there is common cultural profile for successful Lean organizations.

Pakdil and Leonard (2015) examined the interconnection of societal culture and lean processes by using national model of Hofstede (1984). The authors understood that collectivist cultures, low uncertainty avoidance-oriented societal cultures, and low power distance-oriented cultures are more focused on employee involvement and creativity at team level. Whereas, opposite cultures are focused on control and standardization. Bortolotti et al., (2015) in along with Kull et al., (2014) analysed the culture of Lean organizations by using GLOBE model. On the one hand, Bortolotti et al., (2015) examined soft practices and includes that all Lean organizations share common cultural characteristics including a higher institutional collectivism, future orientation, a humane orientation, and a lower level of assertiveness. On the other hand, Kull et al., (2014) analysed hard practices and provided organizational culture for predicting effectiveness of Lean which it consists of high uncertainty avoidance, low assertiveness, low future orientation, and low performance orientation.

Both, literature review and conducted interviews, reveal that national culture has a great influence during Lean implementation and it seems interesting to be able to assess the lack of alignments between both cultures in order to manage and facilitate a sustainable implementation. Hence, in this paper, an evaluation model is proposed to help managers in determining the cultural weaknesses before Lean implementation and gives them some recommendations to minimize problems due to cultural aspects.

\section{Evaluation Model}

To create the evaluation model, organizational culture of Toyota and cultural profiles of successful Lean organizations were scrutinized. Since, the cultural models targeted different respondents, including non-managerial employees in Hofstede (1984); managerial employees in GLOBE (House et al., 2004); both managers and employees in Trompenaars and Hampden-Turner (1997), it seems that different aspects were observed in each model. Therefore, dimensions of three models were grouped and integrated into one. The indicators of each dimension were recognized as a result of both literature review and conducted interviews. Moreover, we have provided the level of each dimension that fits with Lean culture including Low, Moderate, or High. The proposed model includes six dimensions which are explained next.

\subsection{Authority Distribution}

Authority Distribution shows how much employees accept a person in higher position has larger power. For this dimension, we grouped Power distance dimension from both Hofstede (1984) and GLOBE (House et al., 2004) models and Achievement/Ascription dimension from Trompenaars \& Hampden-Turner (1997) model.

In the lowest level, managers respect to the experience of employees so that they have unlimited power to decide. Therefore, employees expect to be consulted (Hofstede, 1984). However, this makes it difficult to establish a clear strategic direction (Bortolotti, et al., 2015).

In the high level, there is an order of authority among employees and independent behaviour is not encouraged. Upward mobility is limited; Information is localized and hoarded; Formality is used highly in interactions with others (House et al., 2004). In such organizations, it is accepted that everybody has a place. Therefore, interactions and attitudes are defined by the status. For example, the appropriate person in business's meetings must be the person with equivalent status. Otherwise, the meetings would be delayed or cancelled (Fenwick, et al., 2003). As result of tight control, employees are kept satisfied by offering more job security (Hauff, et al., 2015).

Table 1 illustrates characteristics of Lean organization derived from interviews together with the codes (i.e. main successful factors) as well as related sub-codes (i.e. related practices) that we considered for this dimension. In fact, these were presented as critical factors for successful Lean implementation by previous studies as well (Sim \& Chiang, 2012; Dave, 2013; Gupta \& Jain, 2013; Martínez-Jurado, Moyano-Fuentes \& Jerez-Gómez, 2014; Pentlicki, 2014). 
The interviews reveal that in Lean organizations, employees are trained enough, have enough authority to make decisions, and propose their suggestions. However, they are not allowed to do dramatic changes freely. Employees have the same opportunity to promote to higher managerial positions. Employees prefer equality and a decentralization of power and decision-making; Upward mobility is common; Slow decision making process shows that there is no one top guy who can take decision like in more hierarchical organization; Communication is direct and participative (House et al., 2004).

\begin{tabular}{|l|l|l|}
\hline \multicolumn{1}{|c|}{ Codes } & \multicolumn{1}{|c|}{ Sub-codes } & \multicolumn{1}{c|}{ Interview responses } \\
\hline $\begin{array}{l}\text { Employees } \\
\text { participation }\end{array}$ & Suggestion system & $\begin{array}{l}\text { Suggestion process is implemented in all factories to involve in daily activities. } \\
\text { People lead all Kaizen changes in the line and it is asked to give the information, } \\
\text { from their own perspective, for solving problems. }\end{array}$ \\
\hline $\begin{array}{l}\text { Employees' } \\
\text { empowerment }\end{array}$ & $\begin{array}{l}\text { Authority } \\
\text { distribution }\end{array}$ & $\begin{array}{l}\text { Authority is delegated to employees depending on the level of the training and } \\
\text { implementation of Lean. There is a possibility for employees to adapt the } \\
\text { standard but they cannot change the standard easily on their own. }\end{array}$ \\
\hline $\begin{array}{l}\text { Management and } \\
\text { Leadership }\end{array}$ & Support & $\begin{array}{l}\text { If the problem is so severe to solve, the top manager goes directly to shop floor } \\
\text { to visit the place where the problem has happened. }\end{array}$ \\
\hline $\begin{array}{l}\text { Employees' } \\
\text { training }\end{array}$ & training & $\begin{array}{l}\text { Several levels of training are considered and training programs continue until the } \\
\text { last level. The specific number of employees is chosen to be trained to work in } \\
\text { another area depending on the needed percentage of flexibility in each area. }\end{array}$ \\
\hline $\begin{array}{l}\text { Management and } \\
\text { leadership }\end{array}$ & Job promotion & $\begin{array}{l}\text { There is normally an internal system about vacancies and employees can send } \\
\text { their proposal for the position. Human resource management evaluates proposals } \\
\text { based on feedbacks of their manager and they will be interviewed as a normal } \\
\text { candidate. }\end{array}$ \\
\hline
\end{tabular}

Table 1. Quotes of interviews related to dimension 1

Therefore, based on both interviews and literature review, we assume that Lean organization has Moderate level of Authority Distribution.

\subsection{Sense of Belonging to the Organization}

This dimension shows how much employees perceive they are dependent to the organization and the success of organization is dependent on them. According to Recht and Wilderom (1998), creating a shared fate nurtures the commitment of employees and thus, they are more willing to share or apply their knowledge and experiences. For this dimension, we grouped Collectivism dimension from Hofstede (1984), Institutional and In-Group Collectivism, Human Orientation, Gender Egalitarianism and Assertiveness from GLOBE (House et al., 2004) model and Communitarianism/Individualism, Outer direction/Inner direction from Trompenaars \& HampdenTurner (1997) model.

In the lowest level, employees suppose that their interests are independent to the organization. Therefore, their selfinterest is important. Communications are direct and unambiguous. They are mostly motivated by a need for power and material possessions (House et al., 2004). In such organizations, people believe that they can control their environment to achieve goals (Trompenaars \& Hampden-Turner, 1997). Moreover, hiring and promotion decisions are based on what one has done and critical decisions are made by individuals (Hofstede, 1984).

In the high level, employees are willing to collaborate in teams (Parkes, 2014; Bortolotti et al., 2015; Martins et al., 2015). Fairness, interpersonal care, mutual trust, and respect are easily visible in the organization (Kull et al., 2014). People are proud of their organization so that they are loyal (Bortolotti, et al., 2015). In addition, they are willing to maximize interests of the organization (Kull et al., 2014).

The moderate level of this dimension does not indicate a strong preference to either end of the scale. 
With regard to Table 2, interviews reveal that Lean culture encourages employees to feel that the organization is their own. Additionally, according to Kull et al. (2014) and Bortolotti et al. (2015), employees are highly committed and involved themselves to improve the organization in all aspect.

\begin{tabular}{|l|l|l|}
\hline \multicolumn{1}{|c|}{ Codes } & \multicolumn{1}{|c|}{ Sub-codes } & \multicolumn{1}{c|}{ Interview responses } \\
\hline $\begin{array}{l}\text { Employees' } \\
\text { participation }\end{array}$ & Motivating system & $\begin{array}{l}\text { Employees are motivated to participate through the authority delegated to each } \\
\text { business unit so that they can manage processes, KPIs and budget on their own. } \\
\text { As a result, they feel that they have the ownership of the cell. }\end{array}$ \\
\hline Work teams & Team building & $\begin{array}{l}\text { Creating work teams is the first priority for Lean implementation. Team leaders } \\
\text { are selected from strong people. They are responsible to develop capabilities of } \\
\text { their team members in the weekly kaizen events. }\end{array}$ \\
\hline
\end{tabular}

Table 2. Quotes of interviews related to dimension 2

In addition, literature review discloses that Lean practices do not differentiate on gender (Kull et al., 2014). Therefore, regardless of gender, all employees have the same opportunity to promote to higher position or receive necessary trainings. Other important factors that influence on Lean implementation are: job satisfaction (Sim \& Chiang, 2012; Taylor et al., 2013; Dora et al., 2016), job security (Scherrer-Rathje, et al., 2009; Sim \& Chiang, 2012; Dave, 2013; Poksinska, Swartling \& Drotz, 2013; Taylor, et al., 2013; Sisson \& Elshennawy, 2015; Dora et al., 2016), and fair reward (Sim \& Chiang, 2012; Dave, 2013; Taylor et al., 2013; Dora et al., 2016).

Therefore, the Sense of Belonging to the Organization is in High level for Lean culture.

\subsection{Courage to Accept Changes}

This dimension demonstrates how much employees are ready and motivated to accept changes and challenge themselves. Creating any change in the way of daily working increases workloads for employees. Being taught performing multi-tasks and cross-functional jobs are huge for employees to resist the implementation. In fact, literature review reveals that "employee resistance to change" hinders successful Lean implementation (ScherrerRathje et al., 2009; Sim \& Chiang, 2012). For this dimension, we grouped Uncertainty Avoidance dimension from Hofstede (1984) and GLOBE (House et al., 2004) models and Particularism/Universalism dimension from Trompenaars \& HampdenTurner (1997) model.

According to House et al. (2004), in the lowest level, employees rely on formalized policies and procedures. Employees take moderate, carefully calculated risks. Employees use formality in interactions with others. Employees show strong resistance to change.

In the high level, employees are informal in interactions with others. They are less orderly and keep fewer records. They rely on informal norms for most matters. They are less calculating when taking risks (House et al., 2004).

The Moderate level of this dimension shows that employees do not have any preferences in dealing with new work methods (Hofstede, 1984).

Literature reveals that successful Lean implementation begins with listening to people and acknowledging their concerns (Sim \& Chiang, 2012; Taylor et al., 2013). Leadership support and a disclosure of what is going on will prevent confusions that cause employees' resistance (Scherrer-Rathje, et al., 2009; Poksinska, et al., 2013; Sisson \& Elshennawy, 2015). Moreover, interviews unfolds (Table 3) that successful organizations announce any changing programs prior to applying in order to lessen any distress. 


\begin{tabular}{|l|l|l|}
\hline \multicolumn{1}{|c|}{ Codes } & \multicolumn{1}{|c|}{ Sub-codes } & \multicolumn{1}{c|}{ Interview responses } \\
\hline $\begin{array}{l}\text { Management and } \\
\text { Leadership }\end{array}$ & Communication & $\begin{array}{l}\text { Before implementation, communications are started with all employees about the } \\
\text { project and changes, the KPIs, and the impacts on employees. }\end{array}$ \\
\hline Work teams & $\begin{array}{l}\text { Employees' } \\
\text { reactions }\end{array}$ & $\begin{array}{l}\text { At the beginning, it is hard to move employees from comfortable zone which } \\
\text { they worked for a few years. Therefore, they will expect the increase in payments. }\end{array}$ \\
\hline $\begin{array}{l}\text { Management and } \\
\text { Leadership }\end{array}$ & Support & $\begin{array}{l}\text { Dissatisfactions are heard in both formal and informal meetings. In formal } \\
\text { meetings, employees are obligated to attend. The top manager communicates } \\
\text { with the whole factory and explains what is happening in the business. } \\
\text { Employees can provide feedbacks if they do not like something. }\end{array}$ \\
\hline
\end{tabular}

Table 3. Quotes of interviews related to dimension 3

In addition to formal meetings that let employees know what is happening in the whole factory, informal meetings create the opportunity for employees to discuss their concerns more comfortably. Furthermore, interviews shed light on influences of national culture so that people reactions in different countries are not the same. In this regard, the responses of the interviewee are presented as follows: "Spanish and Italian people are much more complaining about changes that have to be done than British people. American and South American people are more active to participate in the implementation of a new initiative. Later, when people see and feel benefits of changes in the pilot line, they become more motivated to involve". Therefore, the transparency of improvements to the whole plant is a key factor for successful implementation (Martínez-Jurado, et al., 2014).

Hence, Courage to Accept Changes of employees is High in Lean organizations.

\subsection{Performance Orientation}

This dimension indicates general tendency in organization on success; how much employees are being encouraged for innovations, excellence, and performance improvement. This dimension is the outcome of integrating Masculinity/Femininity from Hofstede (1984) and Performance Orientation from GLOBE (House et al., 2004).

According to House et al. (2004), in low level organizations, it is important to keep the life/work balance. An effective manager is supportive to his/her people and decision making is achieved through involvement. Managers strive for consensus and people value equality, solidarity and quality in their working lives. Conflicts are resolved by compromise as well as negotiation. Incentives such as free time and flexible work hours and place are favoured.

In organizations with high level, team performance is valued rather than who has done the work. Daily meeting and formal feedback for performance improvement is necessary. Competitiveness and materialism are valued. Direct, explicit and informal communication is expected (House et al. 2004).

The moderate level of this dimension shows that employees do not have any preference in "wanting to be the best" or "Liking what to do". Moreover, finding the way that motivates employees is very difficult (Hofstede, 1984).

The interviews revealed (Table 4) that a training system is always considered in Lean organization so that the development of employees is always tracked. 


\begin{tabular}{|l|l|l|}
\hline \multicolumn{1}{|c|}{ Codes } & \multicolumn{1}{|c|}{ Sub-codes } & \multicolumn{1}{c|}{ Interview responses } \\
\hline $\begin{array}{l}\text { Management and } \\
\text { leadership }\end{array}$ & Communication & $\begin{array}{l}\text { Information is frequently communicated to employees about safety, quality, } \\
\text { volume, cost structures, and new initiatives that are coming. Employees are } \\
\text { involved in all KPIs. The same KPIs that sent to leadership level are also tracked } \\
\text { in the same way in shop floor level. So, the objectives set on the shop floor and } \\
\text { also the results are all transparent. Then, once all communications are done, } \\
\text { employees return with their questions and feedbacks. }\end{array}$ \\
\hline $\begin{array}{l}\text { Management and } \\
\text { leadership }\end{array}$ & Commitment & $\begin{array}{l}\text { The issues of previous day are considered to be solved. Therefore, meetings are } \\
\text { done daily at the line, area and factory level. }\end{array}$ \\
\hline $\begin{array}{l}\text { Employees' } \\
\text { training }\end{array}$ & Training system & $\begin{array}{l}\text { Trainings always start with basic communications. Then, while tools are being } \\
\text { implemented, more capabilities are taught to them. }\end{array}$ \\
\hline
\end{tabular}

Table 4. Quotes of interviews related to dimension 4

According to this results, Lean organizations are in High level for Performance Orientation.

\subsection{Time Perspective Orientation}

This dimension shows how much employees are willing to delay short-term success or emotional gratification in order to prepare for the future. The dimension is the result of grouping Long/Short Time Orientation from Hofstede (1984), Future Orientation from GLOBE (House et al., 2004), and Sequential/Synchronic Time from Trompenaars \& Hamp-denTurner (1997).

In lower level, organizations focus on the present or past. Feedback cycles are short as well. Employees stick to traditions and view changes with scepticism (House et al., 2004).

In high level, organizations search for persistence rather than immediate results, face perseverance (not showing emotions), saving rather than spending money, and adaptability are valued (House et al., 2004).

In moderate level, the preference cannot be totally determined. Time is not linear, and thus is not as important as to low on this dimension.

According to table 5, one challenge for successful implementation is that managers often expect short-term success whereas it takes a long term for cultural changes to be improved.

\begin{tabular}{|l|l|l|}
\hline \multicolumn{1}{|c|}{ Code } & \multicolumn{1}{|c|}{ Sub-codes } & \multicolumn{1}{c|}{ Interview responses } \\
\hline $\begin{array}{l}\text { Management and } \\
\text { leadership }\end{array}$ & $\begin{array}{l}\text { Top manager } \\
\text { challenges }\end{array}$ & $\begin{array}{l}\text { The important challenge is convince top manager to allocate financial } \\
\text { resources. Because Lean needs cultural change and results will reveal in long } \\
\text { term. Many top managers do not believe in a long term results and they expect } \\
\text { to see improvements in short term. }\end{array}$ \\
\hline Team works & Cultural change & It usually takes 3 years to see cultural changes in one work centre. \\
\hline
\end{tabular}

Table 5. Quotes of interviews related to dimension 5

Lean organizations are High in Time Perspective Orientation.

\subsection{Lively Spirit Orientation}

This dimension shows how much organizational culture facilitates human interaction within or outside of workplace and strives to generate company unity. For this dimension, we grouped Indulgence/Restraint dimension from Hofstede (1984) and Diffuse/Specific and Neutral/Emotional dimension from Trompenaars \& HampdenTurner (1997) model.

In the lowest level, employees have a tendency to cynicism and pessimism. They do not put much emphasis on leisure time and control the gratification of their desires. People with this orientation have the perception that their actions are restrained by social norms and feel that indulging themselves is somewhat wrong (Hofstede, 
1984). People keep work and personal lives separate. As a result, they believe that relationships don't have much of an impact on work objectives. People make a great effort to control their emotions. Reason influences their actions far more than their feelings. People don't reveal what they're thinking or how they're feeling (Mind Tools Coporation, 2014).

In higher level, the overlap between employees' work and personal life is conspicuous. Vibrant and happy work place is highly valued in such organization. People spend time outside work hours with colleagues and clients (Mind Tools Coporation, 2014). They possess a positive attitude and have a tendency towards optimism. In addition, they place a higher degree of importance on leisure time, act as they please (Hofstede, 1984). People want to find ways to express their emotions, even spontaneously, at work. In these cultures, it's welcome and accepted to show emotion (Mind Tools Coporation, 2014).

The moderate level shows adequate emphasis on leisure time and control the gratification of desires (Hofstede, 1984).

Interviews showed that although there is a friendly relationship between employees, they do have boundaries to avoid the conflicts.

Therefore, lean organizations have Moderate level of Lively Spirit Orientation.

\section{Discussions}

This study was conducted with the focus on proposing an evaluation model which empowers decision makers to assess their compatibility of organizational culture to Lean culture before any deployment. Literature review revealed that national culture differences influence on Kaizen programs adoption and Lean transfer (Wong, 2007; Yokozawa, et al., 2010; Yokozawa \& Steenhuis, 2013; James \& Jones, 2014; Wangwacharakul, et al., 2014; Pakdil \& Leonard, 2015; Tsao, Rau \& Ma, 2015; Zimmermann \& Bollbach, 2015). Moreover, some studies examined cultural profile of Lean organization through GLOBE model (House et al., 2004) which the results are in contradictions (Kull et al., 2014; Bortolotti et al., 2015). However, no studies could be found on how to adapt organizational culture with Lean culture when national culture is not compatible. Therefore, this model can help companies to identify the main aspects to consider before implementing lean.

In order to consider influences of national culture, we combined three national culture models including Hofstede (1984), GLOBE (House et al., 2004), and Trompenaars and Hampden-Turner (1997) and propose a model to facilitate changes for Lean transformation. Figure 1 shows the proposed model to assess organizational culture compatibility to Lean culture. At Level 1, Lean culture appears as ideal culture. The second level indicates six dimensions that we propose. Next, we add the right level for a successful Lean implementation and the indicators corresponding to each dimension are presented at the fourth level.

The first dimension, Authority Distribution, refers to how decisions are made in the organization. The ideal level for this dimension is Moderate. To deal with employees coming from nations with high level, Mind Tools Coporation (2014) recommends to use titles, especially when these clarify people's status in an organization, show respect to people in authority, especially when challenging decisions are being made. Whereas, to collaborate with people coming from low level it is better to recognize and reward good performance as well as be a good role model.

The second dimension, Sense of Belonging to the Organization, shows how much employees are bonded to the organization. The best level that fits with Lean organization is High. To collaborate with employees that come from nations in low level, it is better to link people's needs with group's needs, manage conflicts quickly and quietly, encourage others to take responsibility for their work, and reassure them that they are doing a good job (Mind Tools Coporation, 2014).

The third dimension, Courage to Accept Changes, determines how much employees are ready to apply changes to their habitual work. The perfect level for Lean organization is High. For the organizations in opposite level, the following strategies are recommended: help people understand how their work ties into their values and beliefs. Provide clear instructions, processes, and procedures. Keep promises and be consistent. Give people time to make 
decisions. Use an objective process to make decisions yourself, and explain your decisions if others are involved (Mind Tools Coporation, 2014).

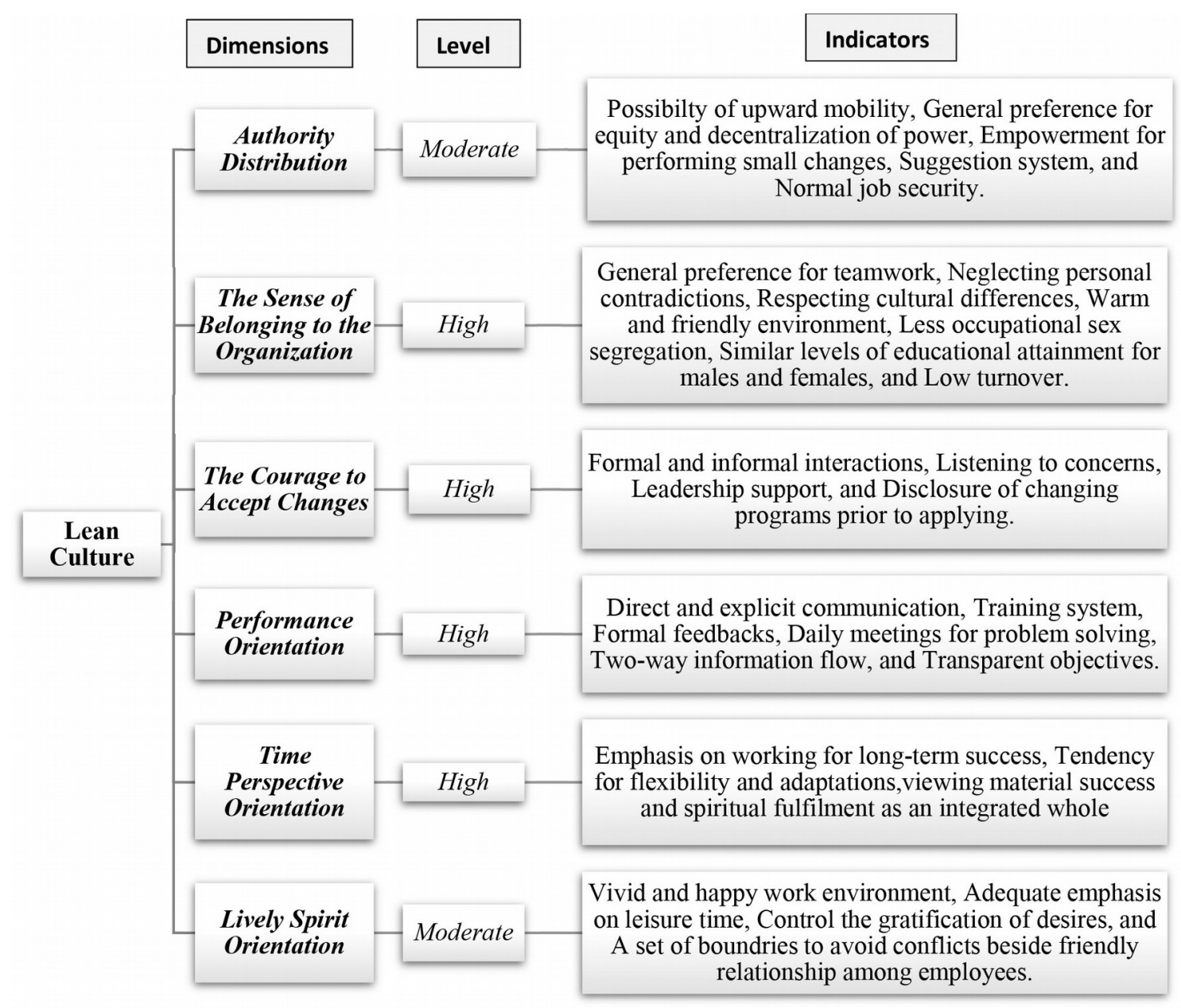

Figure 1. Evaluation Model

The fourth dimension, Performance Orientation, demonstrates the general view of organization to success and how much performance improvement is valued. Lean organization has High level in this dimension.

The fifth dimension, Time Perspective Orientation, indicates for how long the organization allocates resources to achieve the expected results or success. The ideal level for these dimensions is High. To work with employees that oriented in low level of Time perspective is better to set clear deadlines and stick to them and focus on a few activities or projects at a time (Mind Tools Coporation, 2014).

The sixth dimension, Lively Spirit Orientation, expresses how much the organization values friendly and happy work environment. Lean organizations are in Moderate level. To interact with employees from high level, it is recommended to use emotions to communicate your objectives. Be prepared to discuss business on social occasions, and to have personal discussions at work. Japanese people have the low level whereas human relations activities called HUREAI at Toyota strengthen teamwork and communication by widening the circle of human interaction. To interact with the employees from low level, it is recommended to manage emotions; watch people's reactions carefully, be direct to the point; provide clear instructions, processes, and procedures. 


\section{Conclusions}

We propose an evaluation model to assess cultural adaptations to Lean culture with some managerial recommendations as a result of integrating three national culture model including Hofstede (1984), GLOBE (House et al., 2004), and Trompenaars \& Hampden-Turner (1997). The model will be applicable in all organizations regardless of geographical location, size and industry.

To best of our knowledge, this study is the first attempt that integrated the national models with organizational culture and proposes an evaluation model and some recommendations to adapt corporate culture before implementing Lean. However, more research has to be done in this field to identify best practices in successful Lean organization from different countries to strengthen our model.

Future research can be devoted to validate the degree of influence of each dimension by means of multiple case studies among successful Lean organizations from several countries. Moreover, case studies can also help to identify more managerial recommendations in dealing with inconsistent cultural characteristics with Lean culture.

\section{Declaration of Conflicting Interests}

The authors declared no potential conflicts of interest with respect to the research, authorship, and/or publication of this article.

\section{Funding}

The authors received no financial support for the research, authorship, and/or publication of this article.

\section{References}

Abrahamsson, S., \& Isaksson, R. (2012). Implementing Lean-Discussing Standardization versus Customization with Focus on National Cultural Dimensions. Management and Production Engineering Review, 3(4), 4-13. https://doi.org/10.2478/v10270-012-0029-6

Achanga, P., Shehab, E., Roy, R., \& Nelder, G. (2006). Critical success factors for lean implementation within SMEs. Journal of Manufacturing Technology Management, 17(4), 460-471. https://doi.org/10.1108/17410380610662889

Alves, A.C., Dinis-Carvalho, J., \& Sousa, R.M. (2012). Lean production as promoter of thinkers to achieve companies' agility. The Learning Organization, 19(3), 219-237. https://doi.org/10.1108/09696471211219930

Alvesson, M. (2012). Understanding organizational culture. Sage.

Angelis, J., Conti, R., Cooper, C., \& Gill, C. (2011). Building a high-commitment lean culture. Journal of Manufacturing Technology Management, 22(5), 569-586. https://doi.org/10.1108/17410381111134446

Atkinson, P. (2010). Lean is a cultural issue. Journal of the Institute Management Services, 54(2), 35-41. Available at: http://www.ims-productivity.com/user/custom/journal/2010/summer/MSJ\%20Summer $\% 202010 \% 20$ LRes.pdf\#page $=35$

Bhasin, S. (2012a). Performance of Lean in large organisations. Journal of Manufacturing Systems, 31(3), 349-357. https://doi.org/10.1016/j.jmsy.2012.04.002

Bhasin, S. (2012b). Prominent obstacles to lean. International Journal of Productivity and Performance Management, 61(4), 403-425. https://doi.org/10.1108/17410401211212661

Bortolotti, T., Boscari, S., \& Danese, P. (2015). Successful lean implementation: Organizational culture and soft lean practices. International Journal of Production Economics, 160, 182-201. https://doi.org/10.1016/j.ijpe.2014.10.013

Cagliano, R., Caniato, F., Golini, R., Longoni, A., \& Micelotta, E. (2011). The impact of country culture on the adoption of new forms of work organization. International Journal of Operations \& Production Management, 31(3), 297-323. https://doi.org/10.1108/01443571111111937

Dahlgaard, J.J., \& Mi Dahlgaard-Park, S. (2006). Lean production, six sigma quality, TQM and company culture. The TQM magazine, 18(3), 263-281. https://doi.org/10.1108/09544780610659998 
Dailey, K.W., Wieckhorst, D., \& Welch, B. (2003). Lean manufacturing pocket handbook. Published Company.

Dave, Y. (2013).Review of hindering factors to Lean manufacturing'. International Journal of Latest Research in Science and Technology, 2(1), 606-608.

Dombrowski, U., \& Mielke, T. (2014). Lean leadership-15 rules for a sustainable lean implementation. Procedia CIRP, 17, 565-570. https://doi.org/10.1016/j.procir.2014.01.146

Dora, M., Kumar, M., \& Gellynck, X. (2016). Determinants and barriers to lean implementation in food-processing SMEs-a multiple case analysis. Production Planning \& Control, 27(1), 1-23. https://doi.org/10.1080/09537287.2015.1050477

El-Khalil, R., \& Farah, M.F. (2013). Lean management adoption level in middle eastern manufacturing facilities. The Business Review, Cambridge, 2(2), 158-167.

Fenwick, M., Edwards, R., \& Buckley, P.J. (2003). Is cultural similarity misleading? The experience of Australian manufacturers in Britain. International Business Review, 12(3), 297-309. https://doi.org/10.1016/S0969-5931(03)00017-9

Gupta, S., \& Jain, S.K. (2013). A literature review of lean manufacturing. International Journal of Management Science and Engineering Management, 8(4), 241-249. https://doi.org/10.1080/17509653.2013.825074

Hauff, S., Richter, N.F., \& Tressin, T. (2015). Situational job characteristics and job satisfaction: The moderating role of national culture. International business review, 24(4), 710-723. https://doi.org/10.1016/j.ibusrev.2015.01.003

Hines, P., Found, P., Griffiths, G., \& Harrison, R. (2011). Staying Lean: thriving, not just surviving. CRC Press. https://doi.org/10.1201/b10492

Hines, P., Holweg, M., \& Rich, N. (2004). Learning to evolve: a review of contemporary lean thinking. International journal of operations \& production management, 24(10), 994-1011. https://doi.org/10.1108/01443570410558049

Hofstede, G. (1984). Culture's consequences: International differences in work-related values (5). Sage Publications.

Hofstede G., Hofstede, J.G., \& Minkov, M. (2010). Cultures and organizations: Software of the mind. McGaw-Hill, London.

House, R.J., Hanges, P.J., Javidan, M., Dorfman, P.W., \& Gupta, V. (Eds.) (2004). Culture, leadership, and organizations: The GLOBE study of 62 societies. Sage Publications.

James, R., \& Jones, R. (2014). Transferring the Toyota lean cultural paradigm into India: implications for human resource management. The International Journal of Human Resource Management, 25(15), 2174-2191. https://doi.org/10.1080/09585192.2013.862290

Kidd, J.B., \& Kanda, M. (2000). Implementation of strategic plans: a comparison of British and Japanese production managers. International Business Review, 9(5), 641-655. https://doi.org/10.1016/S0969-5931(00)00024-X

Kull, T.J., Yan, T., Liu, Z., \& Wacker, J.G. (2014). The moderation of lean manufacturing effectiveness by dimensions of national culture: testing practice-culture congruence hypotheses. International Journal of Production Economics, 153, 1-12. https://doi.org/10.1016/j.ijpe.2014.03.015

Langstrand, J., \& Elg, M. (2012). Non-human resistance in changes towards lean. Journal of Organizational Change Management, 25(6), 853-866. https://doi.org/10.1108/09534811211280609

Lau, C.M., \& Ngo, H.Y. (1996). One country many cultures: Organizational cultures of firms of different country origins. International Business Review, 5(5), 469-486. https://doi.org/10.1016/0969-5931(96)00022-4

Liker, J., \& Convis, G.L. (2011). The Toyota way to lean leadership: Achieving and sustaining excellence through leadership development. McGraw-Hill Education.

Mann, D. (2014). Creating a lean culture: tools to sustain lean conversions. CRC Press.

Marodin, G.A., \& Saurin, T.A. (2015). Classification and relationships between risks that affect lean production implementation: a study in Southern Brazil. Journal of Manufacturing Technology Management, 26(1), 57-79.

https://doi.org/10.1108/JMTM-12-2012-0113 
Martínez-Jurado, P.J., Moyano-Fuentes, J., \& Jerez-Gómez, P. (2014). Human resource management in lean production adoption and implementation processes: success factors in the aeronautics industry. BRQ Business Research Quarterly, 17(1), 47-68. https://doi.org/10.1016/j.cede.2013.06.004

Martins, A.F., Affonso, R.C., Tamayo, S., Lamouri, S., \& Ngayo, C.B. (2015, October). Relationships between national culture and Lean Management: A literature Review. In 2015 International Conference on Industrial Engineering and Systems Management (IESM), 352-361. IEEE. https://doi.org/10.1109/IESM.2015.7380183

Mike, B., \& Slocum, J.W. (2003). Slice of Reality: Changing Culture at Pizza Hut and Yum! Brands, Inc. Organizational Dynamics, 32(4), 319-330. https://doi.org/10.1016/j.orgdyn.2003.08.005

Mind Tools Coporation. (2014). The Seven Dimensions of Culture Understanding and Managing Cultural Differences. Available at: https://www.mindtools.com/pages/article/seven-dimensions.html

Al-Najem, M. (2014). Investigating the factors affecting readiness for lean system adoption within Kuwaiti small and medium-sized manufacturing industries. Doctoral dissertation. University of Portsmouth.

Nordin, N., Deros, B.M., Wahab, D.A., \& Rahman, M.N.A. (2012). A framework for organisational change management in lean manufacturing implementation. International Journal of Services and Operations Management, 12(1), 101-117. https://doi.org/10.1504/IJSOM.2012.046676

Olivella, J., Cuatrecasas, L., \& Gavilan, N. (2008). Work organisation practices for lean production. Journal of Manufacturing Technology Management, 19(7), 798-811. https://doi.org/10.1108/17410380810898750

Pakdil, F., \& Leonard, K.M. (2015). The effect of organizational culture on implementing and sustaining lean processes. Journal of Manufacturing Technology Management, 26(5), 725-743. https://doi.org/10.1108/JMTM-08-20130112

Parkes, A. (2014). Lean management culture (121). In Small and medium-sized enterprises in the European Union: development challenges in 2014-2020 perspective. Lodz University of Technology Press.

Parkes, A. (2016). Cultural Conditioning of Lean Management in Great Britain. International Journal of Contemporary Management, 15(1), 49-65.

Pentlicki, J.H. (2014). Barriers and success strategies for sustainable lean manufacturing implementation: A qualitative case study. Doctoral dissertation. University of Phoenix.

Pettersen, J. (2009). Defining lean production: some conceptual and practical issues. The TQM Journal, 21(2), 127-142. https://doi.org/10.1108/17542730910938137

Pheng, L.S., \& Shang, G. (2011). Bridging Western management theories and Japanese management practices: Case of the Toyota Way model. Emerald Emerging Markets Case Studies, 1(1), 1-20. https://doi.org/10.1108/20450621111127395

Poksinska, B., Swartling, D., \& Drotz, E. (2013). The daily work of Lean leaders-lessons from manufacturing and healthcare. Total Quality Management \& Business Excellence, 24(7-8), 886-898. https://doi.org/10.1080/14783363.2013.791098

Recht, R., \& Wilderom, C. (1998). Kaizen and culture: on the transferability of Japanese suggestion systems. International business review, 7(1), 7-22. https://doi.org/10.1016/S0969-5931(97)00048-6

Reider, R. (2014). The Search For Best Practices: Doing the Right Thing the Right Way. Business Expert Press.

Salem, R., Musharavati, F., Hamouda, A.M., \& Al-Khalifa, K.N. (2016). An empirical study on lean awareness and potential for lean implementations in Qatar industries. The International Journal of Advanced Manufacturing Technology, 82(9-12), 1607-1625. https://doi.org/10.1007/s00170-015-7421-7

Schein, E.H. (2010). Organizational culture and leadership (2). John Wiley \& Sons.

Scherrer-Rathje, M., Boyle, T.A., \& Deflorin, P. (2009). Lean, take two! Reflections from the second attempt at lean implementation. Business horizons, 52(1), 79-88. https://doi.org/10.1016/j.bushor.2008.08.004

Schneider, S.C., \& De Meyer, A. (1991). Interpreting and responding to strategic issues: The impact of national culture. Strategic management journal, 12(4), 307-320. https://doi.org/10.1002/smj.4250120406 
Shah, R., \& Ward, P.T. (2003). Lean manufacturing: context, practice bundles, and performance. Journal of operations management, 21(2), 129-149. https://doi.org/10.1016/S0272-6963(02)00108-0

Sim, K.L., \& Chiang, B. (2012). Lean production systems: Resistance, success and plateauing. Review of business, 33(1), 97.

Sisson, J., \& Elshennawy, A. (2015). Achieving success with Lean: An analysis of key factors in Lean transformation at Toyota and beyond. International Journal of Lean six sigma, 6(3), 263-280. https://doi.org/10.1108/IJLSS-07-20140024

Spear, S., \& Bowen, H.K. (1999). Decoding the DNA of the Toyota production system. Harvard business review, 77, 96-108.

Takeuchi, H. (2008). The contradictions that drive Toyota's success. Strategic Direction, 25(1). https://doi.org/10.1108/sd.2009.05625aad.009

Taylor, A., Taylor, M., \& McSweeney, A. (2013). Towards greater understanding of success and survival of lean systems. International Journal of Production Research, 51(22), 6607-6630. https://doi.org/10.1080/00207543.2013.825382

Trompenaars, F., \& Hampden-Turner, C., (1997). Riding the Waves of Culture: Under-standing Cultural Diversity in Global Business (2nd ed.). New York: McGraw Hill.

Tsao, L., Rau, P.P., \& Ma, L. (2015). Development of a quick instrument measuring Kaizen culture (for Chinese). Procedia Manufacturing, 3, 4708-4715. https://doi.org/10.1016/j.promfg.2015.07.567

Wangwacharakul, P., Berglund, M., Harlin, U., \& Gullander, P. (2014). Cultural aspects when implementing lean production and lean product development-experiences from a Swedish Perspective. Quality innovation prosperity, 18(1), 125-140. https://doi.org/10.12776/qip.v18i1.321

Wilson, L. (2009). How to implement lean manufacturing. McGraw Hill Professional.

Wong, M. (2007). The role of culture in implementing lean production system. Advances in Production Management Systems, 413-422. https://doi.org/10.1007/978-0-387-74157-4_49

Worley, J.M., \& Doolen, T.L. (2006). The role of communication and management support in a lean manufacturing implementation. Management Decision, 44(2), 228-245. https:/ / doi.org/10.1108/00251740610650210

Yokozawa, K., Steenhuis, H.J., \& de Bruijn, E.J. (2012). Factors affecting international transfer of Kaizen. Organization, 2, 2.

Yokozawa, K.O.D.O., Steenhuis, H.J., \& de Bruijn, E.J. (2010). Recent experience with transferring Japanese management systems abroad. Journal of Strategic Management Studies, 2(1), 1-16.

Yokozawa, K., \& Steenhuis, H.J. (2013). The influence of national level factors on international kaizen transfer: An exploratory study in The Netherlands. Journal of manufacturing technology management, 24(7), 1051-1075. https://doi.org/10.1108/JMTM-05-2011-0046

Zhou, B. (2016). Lean principles, practices, and impacts: a study on small and medium-sized enterprises (SMEs). Annals of Operations Research, 241(1-2), 457-474. https://doi.org/10.1007/s10479-012-1177-3

Zimmermann, A., \& Bollbach, M.F. (2015). Institutional and cultural barriers to transferring Lean production to China: Evidence from a German automotive components manufacturer. Asian Business \& Management, 14(1), 53-85. https://doi.org/10.1057/abm.2014.18

Journal of Industrial Engineering and Management, 2018 (www.jiem.org)

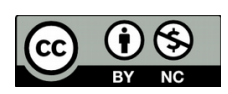

Article's contents are provided on an Attribution-Non Commercial 4.0 Creative commons International License. Readers are allowed to copy, distribute and communicate article's contents, provided the author's and Journal of Industrial Engineering and Management's names are included. It must not be used for commercial purposes. To see the complete license contents, please visit https://creativecommons.org/licenses/by-nc/4.0/. 